\title{
IMPLEMENTATION OF HACCP TO CHICKEN SAUSAGE PRODUCTION LINE
}

Shalaby, M. T.1; Nabila Y. El-Sanafiry²; Amalika D. El-Dhshan ${ }^{1}$ and M. F. Abd El-Salam²

${ }^{1}$ Food Industries Dept., Fac. of Agric., Mans. Univ., Egypt.

2 Meat and Fish Technology Res. Dept., Food Technology Res. Institute, Agric. Res. Center, Giza, Egypt.

\begin{abstract}
Nowadays Hazard Analysis of Critical Control Points (HACCP) has become a prerequisite for transactions involving food products. Whereas the implementation of the Hazard Analysis Critical Control Point (HACCP) system to chicken products is of great importance in order to produce microbiologically safe foods. Chicken sausage is one of the popular foodstuffs among products of chicken meat. Therefore a thorough HACCP analysis of this product has become an important issue for public health. This paper presenting guidelines for the application of HACCP and focuses on the flow diagrams based on the production line of manufacture chicken sausage in a small producing unite in Agriculture Research Center, and presents an analysis of the hazards and of the critical control points (CCP) and monitoring them then verification to confirm that the HACCP system is working effectively.

Keywords: HACCP; Chicken sausage.
\end{abstract}

\section{INTRODUCTION}

In the early 1960s, HACCP concept was originally developed as a microbiological safety system by the Pillsbury Company, in a joint effort with the National Aeronautic and Space Administration (NASA) and the US Army Laboratories at Natick. It was used as a zero defect programmeme aiming at the safe production of foods that would be consumed in zero gravity to ensure that the foods for the space programme were free of all pathogens that could cause illness to astronauts during space travel. Thereafter, the food industry introduced the same system to prevent any risk to the health of its consumers. It was first applied to low-acid can foods with great success (Bauman, 1974; Bryan, 1992 and Michalis and loannis 2000).

The concept of Hazard Analysis of Critical Control Points (HACCP) is a preventive, structured, systematic and documented approach to ensure food safety (Buchanan, 1990). HACCP is an effective precautionary control system that, if applied correctly and systematically, offers the means for the identification and assessment of any possible physical, chemical and microbiological hazards, the detection and control of critical points in all food production steps (Archer, 1990). Hazard assessment and critical control points (HACCP) is worldwide considered as an effective and rational means of assuring food safety, which can be applied throughout the food chain from primary production to final consumption. It is a system aiming at the production of zero defective products which separates the acceptable from 
the non-acceptable (Mauropoulos and Arvanitoyannis, 1999). The Codex Committee on Food Hygiene (FAO/WHO, 1996) stated that, microbiological safety of foods is principally assured by control at the source, product design and process control, and the application of good hygienic practices during production, processing, and handling, distribution, storage, sale, preparation and use. This philosophy is the basis of the HACCP.

Mortimore and Wallace (1998) in brief, HACCP is applied through taking a number of easy steps:

- Look at your process/product from start to finish.

- Decide where hazards could occur.

- Put in controls and monitor them.

- Write it all down and keep records.

- Ensure that it continues to work effectively.

Sperber (2005) mentioned that, in 1972, The Pillsbury Company in the US began the application of its HACCP concept to the manufacture of its consumer food products. This primordial HACCP system consisted of three principles:1) Conduct hazard analysis, 2) Determine critical control points and 3) Establish monitoring procedures.

While Martyn (2000); Mc Swane et al., (2003) and Taylor (2008) reported that, in 1993 the Codex Alimentarius Commission elaborated a 12part method (guidelines) for the application of HACCP. This has achieved international recognition and as such, has become the definitive method of applying HACCP principles. These guidelines include a sequence of activities for the application of HACCP principles, which are outlined in:

1:Assemble the HACCP team.

2:Describe product.

3:Identify intended use.

4:Construct flow diagram.

5:On-site verification of flow diagram.

6:Conduct a hazard analysis: Listing potential hazards and identify preventive measures for significant hazards to reduce or eliminate them.

7:Determine the critical control points (CCPs).

8:Establish critical limit(s) for each CCP: Set target levels and tolerances, which must be met to ensure the CCP is under control.

9:Establish a monitoring system for each CCP: it must be able to detect loss of control at the CCP (those occurrences outside the Critical Limits).

10:Establish the corrective actions to be taken when monitoring indicates that a particular CCP is not under control (a critical limit has been exceeded).

11:Establish procedures for verification to confirm that the HACCP system is working effectively.

12:Documentation and record keeping: documentation examples include the hazard analysis, all the reference documents used in the risk assessment, CCP determination and critical limit determination. Record keeping examples include deviations and corrective action reports. This may be the only part of the HACCP plan that will be audited or reviewed by customers or regulators. 
Considering that, the first 5 steps are preliminary procedures while subsequent 7 steps are HACCP principles.

Sausages are emulsions of the oil in water type; the continuous phase is water and soluble compounds, the disperse is oil, and the emulsifier is protein (Pereira et al., 2000). Chicken meat and its products have experienced increasing popularity and become widely spread all over the world due to offering an excellent source of animal protein and this meat is not the focus of many religious or cultural dietary laws. Chicken sausage is one of the popular foodstuffs among these products (Barbut, 2001).

The aim of this research is expositions that, how to apply the HACCP system on line of chicken sausage production through conducts a hazard analysis, determine CCPs, monitoring them; documentation and verification for obtained the high safe product.

\section{MATERIALS AND METHODS}

\section{Materials:}

\section{Chicken :}

Deboned meat of chicken from supplier to line of manufacture chicken sausage in a small producing unite in Agriculture Research Center.

\section{Other ingredients :}

Skim milk powder, spices \& sausage seasonings, garlic, sheep tail fat, salt (sodium chloride), sodium phosphate and natural casings were collected from a supermarket at Giza. While extruded soy obtained from Food Technology Research Institute.

Culture media for the microbiological assay :

Nutrient agar medium (American Public Health Association "A.P.H.A", 1976) and (Difco, 1984) was prepared for the determination of total plate bacterial count. Whereas MacConkey agar medium was used for coliform bacteria counting. Baird parker agar base medium was used for counting the Staphylococcus aureus bacteria and potato dextrose agar medium was used for yeasts and molds count (Difco, 1984). On the other hand for detection of Salmonella and Shigella used 3 media: Buffered pepton as a pre-enrichment medium, while tetrathionate broth as a selective enrichment broth and the Salmonella-Shigella-agar as a selective plating medium (FDA, 1978 and FAO, 1979).

\section{Methods:}

-Application of HACCP system:

Horchner et al., (2006) recommended these steps to implementation the HACCP system.

1.Assemble the HACCP team (Step1):

2.Fill out product description and intended use forms (Steps 2 and 3): 3.Construct a process flow diagram and conformable with real steps on plant (Steps 4 and 5):

4. Principle 1: Conduct a hazard analysis (Step 6):

5.Principle 2: Determine Critical Control Points (CCPs)(Step 7): 
For each process step where a significant hazard has been identified using CCP decision tree Fig.(1) and your own common sense to determined CCPs.

6.Principle 3: Establish critical limits for each CCP (Step 8):

7.Principle 4: Establish CCP monitoring requirements (Step 9):

8.Principle 5: Establish corrective actions (Step 10):

Fill out "HACCP plan worksheet" to fulfillment previously steps.

9.Principle 6: Establish verification procedures (Step 11):

Microbiological analysis methods:

Samples were taken from steps, which considered CCPs: Chicken meat samples were taken randomly directly when received by sterile knives and transported to the laboratory in icebox. In the same manner sheep tail fat, natural casings, minced garlic and the sterilized bottle, which contain cooled water sample (approx. $150 \mathrm{ml}$ ). Also CCPs samples which taken from different steps in sausage processing plant. Whereas spices \& seasonings, skim milk powder, extruded soy transported to the laboratory without refrigeration (Metaxopoulos et al., 2003).

Sample preparation: $10 \mathrm{gm}$. of each sample (CCPs) were mixed with $90 \mathrm{ml}$ of sterile peptone solution (9 gm peptone / $1 \mathrm{~L}$ distilled water) to give $1 / 10$ dilution. Serial dilutions were prepared to be used for counting several types of bacteria \& yeast and molds.

Total plate bacterial count, coliform count, Staphylococcus aureus count and yeasts and molds count were determined according to the procedures by A.P.H.A (1976) and Difco (1984). On the other hand the presence or absence of Salmonella and Shigella were determined according to the methods described by FAO (1979).

Chemical quality attributes:

1. Determination of thiobarbituric acid (TBA) :

TBA was determined according to the method of Pearson (1991) measurement was carried out colorimetrically at $538 \mathrm{~nm}$. The TBA values were calculated by multiplying the absorbance by the factor of 7.8 and the results were represented as $\mathrm{mg}$ malonaldehyde / $\mathrm{kg}$ sample.

2. Determination of total volatile nitrogen (T.V.N.) :

T.V.N was determined by the method of Winton and Winton (1958) results were represented as $\mathrm{mg}$ T.V.N $/ 100 \mathrm{gm}$ sample.

10.Principle 7: Documentation and record keeping (Step 12):

-Processing/Preparation of chicken sausage :

The minced chicken meat was mixed with spices \& sausage seasoning, salt, minced garlic, skim milk powder, soaked soy extrudate (extruded soy : water ratio 1:1and left $20 \mathrm{~min}$. then minced), minced sheep tail fat, sodium phosphate (dissolved in water) and added cold water or flake ice in a kneading machine until emulsion was produced. Then the emulsion was stuffed into natural casings (from sheep) of different size, using a mechanical stuffer. After that put it in foam plates and packed in polyethylene bags, labeled and the finished product was frozen in the deep freezer at $-18^{\circ} \mathrm{C}$. 
J. Agric. Sci. Mansoura Univ., 33(8), August, 2008

F1

5843 
Shalaby, M. T. et al.

\section{RESULTS AND DISCUSSIONS}

-Application of HACCP system during manufacture chicken sausage :

1. Assemble the HACCP team (Step1):

The core HACCP team include Quality Assurance/Technical, Engineering, microbiologist, HACCP experts and statistical Process control.

2. product description and intended use (Steps 2 and 3):

Product Chicken sausage (a frozen poultry product), containing chicke

meat and other ingredients (sheep tail fat, spices \& seasonin

minced garlic, skim milk powder, soaked soy extrudate, sal

Sold in/ Shelf life/

sodium phosphate). Stuffed in natural casing. Packed i

Storage temp. Supermarkets/ 3 months $/-18^{\circ} \mathrm{C}$.

Intended user Public community.

How it used? After adequate cooking (heated until the core temperature wa raised to $72^{\circ} \mathrm{C}$ approximately).

3. Construct a process flow diagram (Steps 4 and 5):

Fig.(2): Flow diagram of chicken sausage. 
J. Agric. Sci. Mansoura Univ., 33(8), August, 2008

4. HACCP plan work sheet (Steps 6,7,8 and 9):

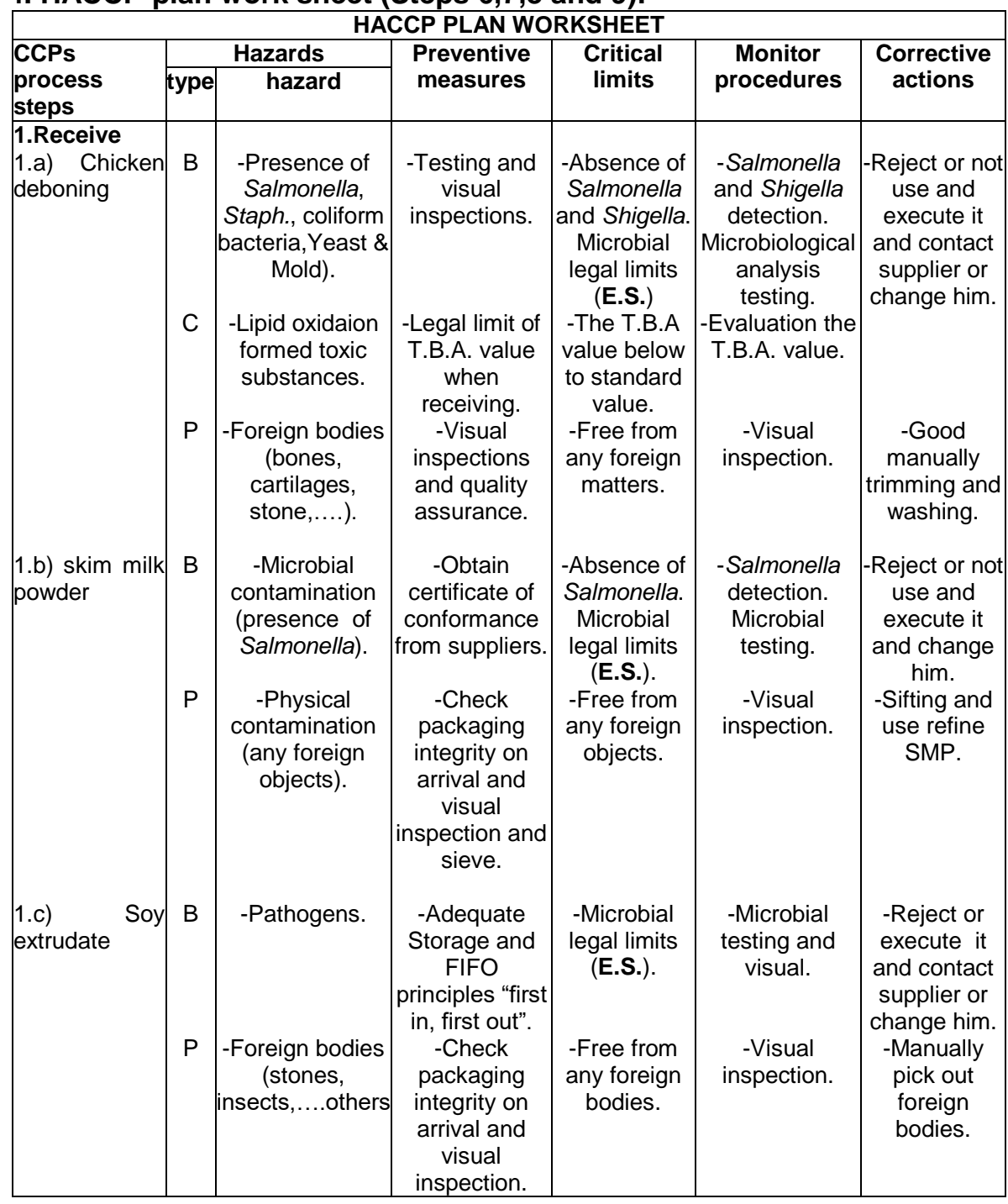


Shalaby, M. T. et al.

Continued.

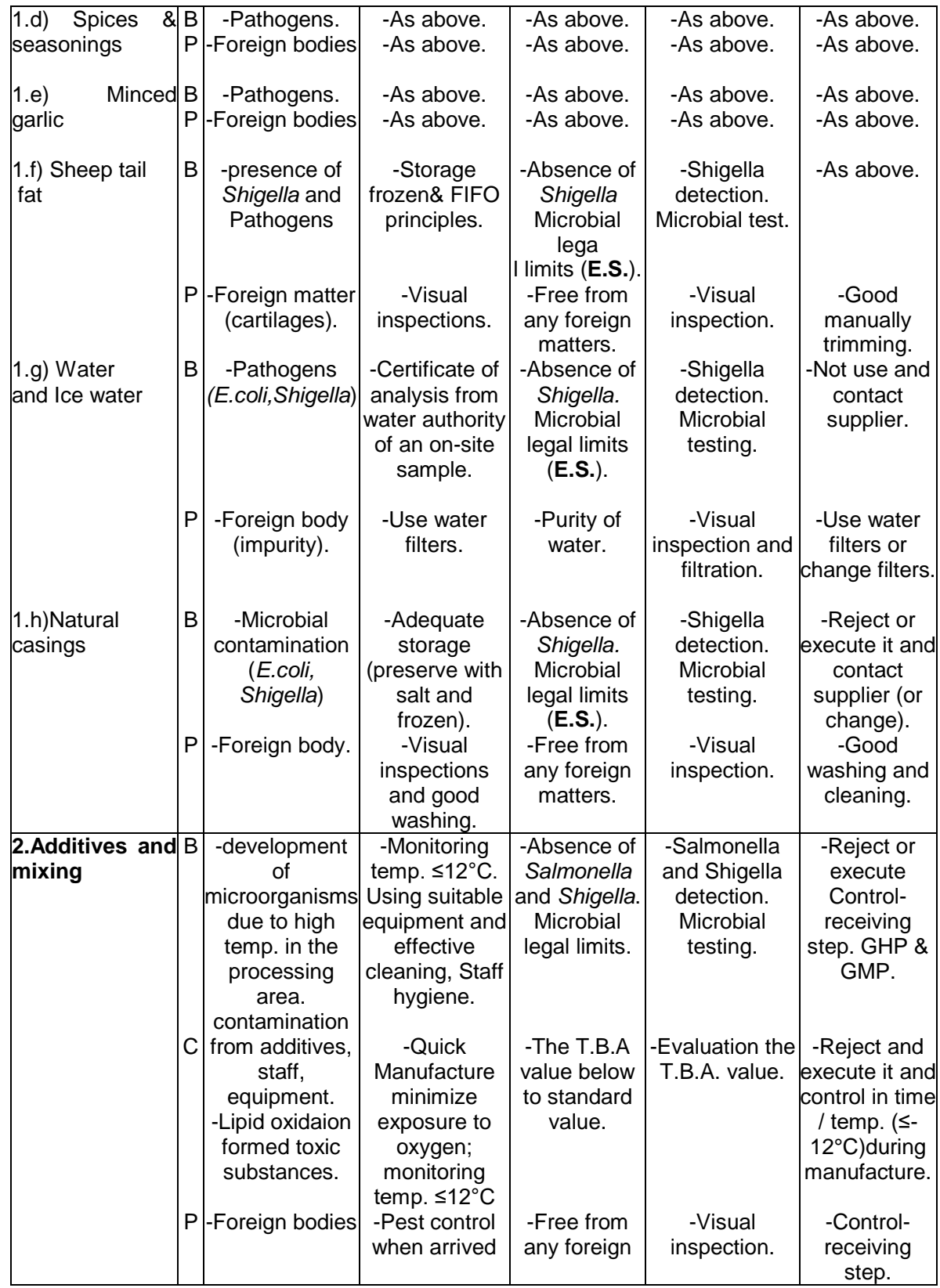


J. Agric. Sci. Mansoura Univ., 33(8), August, 2008

Continued.

\begin{tabular}{|c|c|c|c|c|c|c|}
\hline & & & $\begin{array}{l}\text { additives and } \\
\text { clean utensils. }\end{array}$ & matters. & & $\begin{array}{l}\text { pick out } \\
\text { foreign } \\
\text { bodies }\end{array}$ \\
\hline 3.Stuffing & $\mathrm{B}$ & $\begin{array}{c}\text {-As above and } \\
\text { cross } \\
\text { contamination } \\
\text { from natural } \\
\text { casings. }\end{array}$ & $\begin{array}{c}\text {-Stuffing } \\
\text { quickly for } \\
\text { minimize } \\
\text { exposure to } \\
\text { oxygen; } \\
\text { monitoring of } \\
\\
\text { temp. }\left(\leq 12^{\circ} \mathrm{C}\right) . \\
\text {-Clean } \\
\text { equipment and } \\
\text { surfaces. }\end{array}$ & $\begin{array}{c}\text {-Absence of } \\
\text { Salmonella } \\
\text { and Shigella. } \\
\text { Microbial } \\
\text { legal } \\
\text { limits. }\end{array}$ & $\begin{array}{l}\text {-Salmonella } \\
\text { and Shigella } \\
\text { detection. } \\
\text { Microbial } \\
\text { testing. }\end{array}$ & 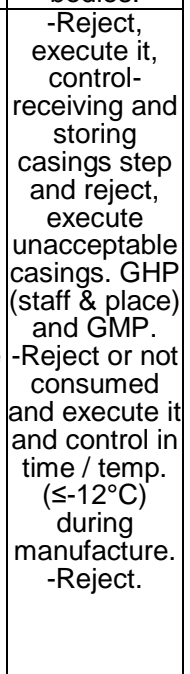 \\
\hline $\begin{array}{l}\text { 4.packaging } \\
\text { \& labeling }\end{array}$ & C & \begin{tabular}{|c|}
-An allergic by \\
some food \\
components (if \\
not mention by \\
label and \\
consumed). \\
-Untraceable \\
product \\
(inability to \\
trace and recall \\
product \\
resulting in \\
unfit product in \\
market place)
\end{tabular} & $\begin{array}{c}\text {-Check product } \\
\text { labels } \\
\text { information } \\
\text { (highlighting } \\
\text { any allergenic } \\
\text { components). } \\
\text {-Check codes } \\
\text { (effective date } \\
\text { and batch } \\
\text { coding). }\end{array}$ & $\begin{array}{l}\text {-Mention all } \\
\text { product- } \\
\text { contents. }\end{array}$ & $\begin{array}{c}\text {-Visual } \\
\text { inspection } \\
\text { (check label). } \\
\\
\\
\text {-Visual } \\
\text { inspection } \\
\text { (check label). }\end{array}$ & $\begin{array}{l}\text {-Quarantine } \\
\text { product and } \\
\text { replace label. } \\
\\
\text {-Quarantine } \\
\text { product and } \\
\text { replace label. }\end{array}$ \\
\hline $\begin{array}{l}\text { 5.Freezing } \\
\text { at }-18^{\circ} \mathrm{C}\end{array}$ & $B$ & $\begin{array}{c}\text {-growth } \\
\text { pathogenic } \\
\text { micro- } \\
\text { organisms } \\
\text { resultant low } \\
\text { temperature } \\
\text { not achieved } \\
\text { (abused temp.) } \\
\text { \& poor freezer } \\
\text { cleaning. }\end{array}$ & \begin{tabular}{|c|}
-Control of \\
freezer temp. \\
which restricts \\
microbial \\
growth, \\
monitoring of \\
internal \\
product \\
temperature on \\
exit \\
$<-18^{\circ} \mathrm{C}$ and \\
effective \\
cleaning \\
(procedures \& \\
practices). \\
- Packaging \\
integrity for \\
minimize \\
exposure to \\
oxygen; \\
monitoring of \\
freezing temp. \\
( 5 \\
$\left.-18^{\circ} \mathrm{C}\right)$. \\
\end{tabular} & \begin{tabular}{|c|}
-Freezer \\
temp. $<-$ \\
$18^{\circ} \mathrm{C}$. \\
-Absence of \\
Salmonella \\
and Shigella. \\
Microbial \\
legal limits \\
(E.S.). \\
\\
\\
\\
-The T.B.A \\
value below \\
to standard \\
value.
\end{tabular} & \begin{tabular}{|c|}
-Check freezer \\
and product \\
temp. by \\
thermometer. \\
-Salmonella \\
and Shigella \\
detection. \\
Microbiolog-ical \\
analysis test.
\end{tabular} & $\begin{array}{c}\text {-Alert } \\
\text { procedures } \\
\text { thus adjust } \\
\text { temp. control } \\
\text { on freezer. } \\
\text {-Discard and } \\
\text { execute if } \\
\text { contamina- } \\
\text { tions is } \\
\text { evident. }\end{array}$ \\
\hline
\end{tabular}

\# B= biological hazard, $\mathrm{C}=$ chemical hazard, $\mathrm{P}=$ physical hazard and (E.S.)= Egyption Standards. 
5. Establish verification procedures (Step 11):

Catherine, (1990), demonstrated that, the HACCP system was designed to ensure the safety of meat and poultry products, since receiving raw materials and during processing operations by controlling all steps of production. Thus in our research from fig (2), which presented flow diagram for manufacture of frozen chicken sausage with estimating the CCPs, we determined 5 critical control points, including:1) Receiving raw materials (deboned chicken, additives and stuffing materials); 2) Additives and mixing step; 3) Stuffing step; 4) Packing and labeling step (label's data) and 5) Freezing at $-18^{\circ} \mathrm{C}$. Also some microbiological and chemical analysis were used to monitor and verificate HACCP system to insure producing high quality and safe products for consumers according to the Egyptian Standards as critical limits.

\section{Microbiological analysis:}

Receiving raw materials was a CCP step thus we should assure that the raw materials should having high degree of safety and storage conditions should be good before its use. According to Abd El-Razik (1997) who referred that, since the receiving step in chicken sausage manufacture was determined as a Critical Control Point (CCP), much attention must be taken when analyzing the microbiological quality of raw chicken carcasses and should be kept under frozen storage or even at chilling temperatures until manufacture.

Table (1): Microbiological analysis of received raw materials [CCP1].

\begin{tabular}{|l|c|c|c|c|c|c|c|c|c|}
\hline & \multicolumn{7}{c|}{$\begin{array}{c}\text { Main } \\
\text { material }\end{array}$} & \multicolumn{7}{|c|}{ Additives } & $\begin{array}{c}\text { Stuff } \\
\text { material }\end{array}$ \\
\cline { 2 - 11 } & $\begin{array}{c}\text { Chicken } \\
\text { deboning }\end{array}$ & $\begin{array}{c}\text { Skim } \\
\text { Milk } \\
\text { powder }\end{array}$ & $\begin{array}{c}\text { Soy } \\
\text { extrudate }\end{array}$ & $\begin{array}{c}\text { Spices \& } \\
\text { seasonings }\end{array}$ & $\begin{array}{c}\text { Minced } \\
\text { garlic }\end{array}$ & $\begin{array}{c}\text { Sheep } \\
\text { Tail Fat }\end{array}$ & Water & Ice water & $\begin{array}{c}\text { Natural } \\
\text { casings }\end{array}$ \\
\hline T.B. count & $168 \times 10^{2}$ & $1 \times 10^{2}$ & $4.45 \times 10^{2}$ & $1.05 \times 10^{2}$ & $5 \times 10^{2}$ & $1.7 \times 10^{2}$ & $0.1 \times 10^{2}$ & $0.07 \times 10^{2}$ & $0.7 \times 10^{2}$ \\
\hline $\begin{array}{l}\text { Coliform } \\
\text { count }\end{array}$ & $0.45 \times 10^{2}$ & 0 & $0.7 \times 10^{2}$ & $0.1 \times 10^{2}$ & $0.03 \times 10^{2}$ & 0 & 0 & 0 & $1.2 \times 10^{2}$ \\
\hline $\begin{array}{l}\text { Staph. } \\
\text { count }\end{array}$ & $2.5 \times 10$ & 0 & $0.5 \times 10$ & 0 & 0 & $2 \times 10$ & 0 & 0 & 0 \\
\hline Y\&M count & $14.5 \times 10$ & $0.1 \times 10$ & $0.8 \times 10$ & $0.5 \times 10$ & $1.5 \times 10$ & $1.8 \times 10$ & 0 & 0 & 0 \\
\hline Salmonella & - & - & - & - & - & - & - & - & - \\
\hline Shigella & - & - & - & - & - & - & - & - & - \\
\hline
\end{tabular}

From the data in Table (1), showed that, when receiving raw materials (CCP1) the total bacterial count was $168 \times 10^{2}, 1 \times 10^{2}, 4.45 \times 10^{2}, 1.05 \times 10^{2}$, $5 \times 10^{2}, 1.7 \times 10^{2}, 0.1 \times 10^{2}, 0.07 \times 10^{2}$ and $0.7 \times 10^{2} \mathrm{cfu} / \mathrm{g}$, Colifrom count was $0.45 \times 10^{2}, 0,0.7 \times 10^{2}, 0.1 \times 10^{2}, 0.03 \times 10^{2}, 0,0,0$ and $1.2 \times 10^{2} \mathrm{cfu} / \mathrm{g}$, while Staph. aureus count was $2.5 \times 10,0,0.5 \times 10,0,0,2 \times 10,0,0$ and $0 \mathrm{cfu} / \mathrm{g}$ and finally yeast \& mold count was $14.5 \times 10,0.1 \times 10,0.8 \times 10,0.5 \times 10,1.5 \times 10$, $1.8 \times 10,0,0$ and $0 \mathrm{cfu} / \mathrm{g}$ for chicken deboning, skim milk powder, soy extrudate, spices \& seasonings, minced garlic, sheep tail fat, water, ice water and natural casings samples respectively. Furthermore no detection of Salmonella and Shigella was noticed in any raw materials samples. Therefore all raw materials results are in accordance with the Egyptian Standards [Chilling poultry and rabbits 2005/1651; Dried milk 2005/1648; 
Soya protein products 2005/3640; Frozen garlic 2007/3273; Edible tallow which used in food-industry 2005/471; Water, ice and standard methods for test. Part1: drink water 2007/1-190].

Table (2):Microbiological analysis during manufacturing sausage[CCP2, CCP3, CCP5].

\begin{tabular}{|l|c|c|c|}
\hline & $\begin{array}{c}\text { Additives and } \\
\text { mixing [CCP2] }\end{array}$ & $\begin{array}{c}\text { Stuffing } \\
\text { [CCP3] }\end{array}$ & $\begin{array}{c}\text { Freezing -18 } \\
\text { [CCP5] }\end{array}$ \\
\hline T.B. count & $98.5 \times 10^{2}$ & $111.5 \times 10^{2}$ & $109 \times 10^{2}$ \\
\hline Coliform count & $0.40 \times 10^{2}$ & $0.42 \times 10^{2}$ & $0.41 \times 10^{2}$ \\
\hline Staph. count & $3 \times 10$ & $3 \times 10$ & $2.8 \times 10$ \\
\hline Y\&M count & $9 \times 10$ & $9 \times 10$ & $8.4 \times 10$ \\
\hline Salmonella & - & - & - \\
\hline Shigella & - & - & - \\
\hline
\end{tabular}

Data in Table (2), cleared that, during manufacture steps the total bacterial count was $98.5 \times 10^{2}, 111.5 \times 10^{2}$ and $109 \times 10^{2} \mathrm{cfu} / \mathrm{g}$, colifrom count was $0.40 \times 10^{2}, 0.42 \times 10^{2}$ and $0.41 \times 10^{2} \mathrm{cfu} / \mathrm{g}$, while Staph. aureus count was $3 \times 10,3 \times 10$ and $2.8 \times 10 \mathrm{cfu} / \mathrm{g}$ and finally yeast $\&$ mold count was $9 \times 10,9 \times 10$ and $8.4 \times 10 \mathrm{cfu} / \mathrm{g}$. While Salmonella and Shigella detection was negative for additives \& mixing, stuffing, and freezing steps. This result agree with Oteiza et al., 2003 who found that, the range of values of the microorganisms analyzed in 30 sausage samples were: total microbial counts $6.3 \times 10^{3}-$ $2.1 \times 10^{8} \mathrm{cfu} / \mathrm{g}(40 \%$ of the isolated colonies were Gram positive and $60 \%$ Gram negative),molds and yeasts $8.9 \times 10^{1}-6.3 \times 10^{4} \mathrm{cfu} / \mathrm{g}$, total coliforms $1.4 \times 10^{1}-1.1 \times 10^{3} \mathrm{MPN} / \mathrm{g}$, fecal coliforms $7.0-1.5 \times 10^{2} \mathrm{MPN} / \mathrm{g}$. Staph. aureus and B. cereus were not detected. And Álvarez-Astorga et al. 2002; Gill et al. 1997 and Egyptian Standards [Frozen poultry sausage 2005/2911].

\section{Chemical quality attributes:}

The TBA test is widely used for muscle foods (Gray, 1978; Pikul et al., 1984). Lipid peroxides formed by nonenzymatic oxidation and/or lipoxygenase enzyme, can be further metabolized to carbonyl compounds and fatty acids, which affect flavor and form some toxic substances (Cerise at al., 1973). Thus the oxidative rancidity measured by evaluation TBA values.

Abd El-Razik, (1997) mentioned that, total volatile nitrogen (TVN) could be used as an indication for protein degradation during frozen storage. Total volatile nitrogen (TVN) was determined as an index of protein break-down in stored chicken patties.

Table (3): Thiobarbituric acid value T.B.A. \& total volatile nitrogen T.V.N. for CCPs.

\begin{tabular}{|l|c|c|}
\hline CCP & $\begin{array}{c}\text { T.B.A. } \\
\text { (mg malonaldehyde/kg) }\end{array}$ & $\begin{array}{c}\text { T.V.N. } \\
\text { (mg TVN/100g) }\end{array}$ \\
\hline Receiving chicken deboning [CCP1 $\left.1_{a}\right]$ & 0.410 & 13.94 \\
\hline Additives and mixing [CCP2] & 0.732 & 16.09 \\
\hline Stuffing [CCP3] & 0.770 & 16.43 \\
\hline Freezing $-18^{\circ} \mathrm{C}[\mathrm{CCP} 5]$ & 0.778 & 16.47 \\
\hline
\end{tabular}


The data in Table (3), cleared that, the TBA values were $0.410,0.732$, 0.770 and $0.778 \mathrm{mg}$ malonaldehyde/ $\mathrm{kg}$. for CCP1 1 , CCP2, CCP3 and CCP5. There was an increase in the TBA value during manufacturing and freezing at $-18^{\circ} \mathrm{C}$. This increase proved that, some fat was oxidized, and this increase dependent on TBA value in raw chicken, exposure to oxygen, elevated temperature during manufacture and increase fat content (add sheep tail fat) conform with Abd El-Razik, 1997 and Van Laack, 1994.

On the other hand the results in Table (3), indicated clearly that, the amount of TVN was 13.94, 16.09, 16.43 and $16.47 \mathrm{mg} \mathrm{TVN} / 100 \mathrm{~g}$.sample for CCP1a, CCP2, CCP3 and CCP5. Therefore, continuous increase in TVN was noticed. This increase might be attributed to the break-down of nitrogenous substances by microbial activity (specially with raising time/temperature during manufacture) and depended on the amounts of TVN in raw chicken.

These results are in accordance with Egyptian Standards [Chilling poultry and rabbits 2005/1651 and Frozen poultry sausage 2005/2911] as critical limits.

\section{Documentation and record keeping (Step 12):}

Documentation was completed previously by listing of the HACCP team, product description and intended use, flow diagram of the entire process indicating CCPs, hazards and preventive measurements for each CCP, critical limits for each CCP, monitoring systems, corrective actions for deviations, record keeping, and procedures for verification.

\section{CONCLUSION}

The results in this research indicated that, the raw materials used in chicken sausage production were highly safe thus the final product was also highly safe due to application of HACCP system. Implementation of HACCP system is necessary in order to produce a final safe food products.

\section{REFERENCES}

Álvarez-Astorga, M.; Capita, R.; Alonso-Calleja, C.; Moreno, B. and GarcíaFernández, M. C. (2002). Microbiological quality of retail chicken byproducts in Spain. Meat Science, 62, 45-50

A.P.H.A. (1976). American Public Health Association. Compendium of Methods for the Microbiological Examination of Foods. Speck, M. L. ed., Washington, D. C., USA.

Abd El-Razik, M. M. (1997). Studies on the application of Hazard Analysis Critical Control Points (HACCP) programmes in poultry meat. M.Sc., Fac. of Agric., Ain Shams Univ., Egypt.

Archer, D. (1990). The need for flexibility in HACCP. Food Technology, 44 (5), 174-178.

Barbut, S. (2001). Poultry products processing: An industry guide $\left(1^{\text {st }}\right.$ ed.). Boca Raton, FL, USA: CRC Press.

Bauman, H. E. (1974). The HACCP concept and microbiological hazard categories. Food Technology, 9, 28-30. 
Bryan, F. I. (1992). Hazard Analysis Critical Control Points Evaluations. A guide to identifying Hazards and Assessing Risks Associated with Food Preperation and Storage. W.H.O., Geneva.

Buchanan, R. I. (1990). HACCP: a re-emerging approach to food safety. Trends in Food Science and Technology, 1, 104-106.

Catherine, E. Adama (1990). Use of HACCP in meat and poultry inspection. Food Tech. 44:169.

Cerise, L.; Bracco, U.; Horman, I.; Sozzi, T. and Wuhrmann, J. (1973). Cerand erunge des lipid anteils wahend des Reiffung sprozesses. Von Salami aus reinem schwein effeisch Fleichw. 53:223. Cited by Abd ElRazik (1997).

Difco-Manual (1984). Dehydrated culture media and reagents microbiological and clinical laboratory procedures, Pub-Difco-Lab-Detroits Michigan, USA.

FAO (1979). Manuals of food-quality control, 4, microbiological analysis. Food and Agriculture Organization of the United Nations. Rome., pp. C $9-12$ and $\mathrm{DI}-33$.

FAO/WHO (1996) Report of the Twenty-ninth Session of the Codex Committee on Food Hygiene, ALINORM 97/13A, Washington, DC, 2125 October, FAO, Rome.

FDA (1978). Bacteriological Analytical Manual, Fifth Edition. Food and Drug Administration, Washington, D. C.

Gill, C. O.; Rahn, K.; Sloan, K., \& McMullen, L. M. (1997). Assessment of the hygienic performances of hamburger patty production processes. International Journal of Food Microbiology, 36, 171.

Gray, J. I. (1978). Measurment of lipid oxidation : a review. J. Am. Oil Chem. Soc. 55:539 Cited by : Su et al., 1991.

Horchner, P. M.; Brett, D.; Gormley, B.; Jenson I. and Pointon A. M. (2006) HACCP-based approach to the derivation of an on-farm food safety programme for the Australian red meat industry. Food Control 17, 497510.

Martyn, B. (2000)."HACCP in the meat industry". CRC press of Washington, DC, New York, Woodhead Publishing Ltd., Cambridge, England. Pp 67.

Mauropoulos, A. A. and Arvanitoyannis, I. S.(1999). Implementation of hazard analysis critical control point to Feta and Manouri cheese production lines. Food Control, 10, 213-219.

Mc Swane, D.; Rue, N. and Linton, R. (2003). Essentials of food safety and sanitation (3rd ed.). New Jersey: Pearson Education, pp.169-196.

Metaxopoulos, J.; Kritikos, D. and Drosinos, E.H. (2003). Examination of microbiological parameters relevant to the implementation of GHP and HACCP system in Greek meat industry in the production of cooked sausages and cooked cured meat products. Food Control, 14, 323332.

Michalis, M. E and loannis, S. A.(2000). Implementation of HACCP to large scale production line of Greek ouzo and brandy: a case study. Food Control, 11, 19-30. 
Shalaby, M. T. et al.

Mortimore, S. and Wallace, C. (1998). HACCP: a practical approach. (2 ${ }^{\text {nd }}$ ed.). Gaithersburg, Maryland, U.S.A: Aspen Publishers, Inc.pp 1-36.

Oteiza, J. M.; Giannuzzi, L. and Califano, A. N. (2003). Thermal inactivation of Escherichia coli O157:H7 and Escherichia coli isolated from morcilla as affected by composition of the product. Food Research International, 36, 703-712.

Pearson, D. (1991). The Chemical Analysis of Food. National College of Food Technology, University of Reading, Weybridage, Surry, T. and A. Churchill

Pereira, N. R.; Tarley,C.R.T.; Matsushita, M. and Souza, N. A. (2000). Proximate Composition and Fatty Acid Profile in Brazilian Poultry Sausages. Journal of Food Composition and Analysis, 13, 915-920.

Pikul, J.; Leszeynski, D. E.; Bechtel, P. J. and Kummerow, F. A. (1984). Effects of frozen storage and cooking on lipid oxidation in chicken meat. J. Food Sci., 49:838.

Sperber W.H. (2005). HACCP and transparency. Food Control, 16, 505-509.

Taylor, E. (2008). A new method of HACCP for the catering and food service industry. Food Control 19, 126-134.

Van Laack, R. L. J. M. (1994). Spoilage and preservation of muscle foods. In D. M. Kinsman, A. W. Kotula, \& B. C. Breidenstein (Eds.), Muscle foods (pp. 378-405). New York, NY: Chapman \& Hall.

Winton, A. L. and Winton, R. B. (1958). Oxide distillation volumetric method for the determination of volatile nitrogen. The analysis of food, p. 848. John Wileysons, New York, Chapman and Hull, London.

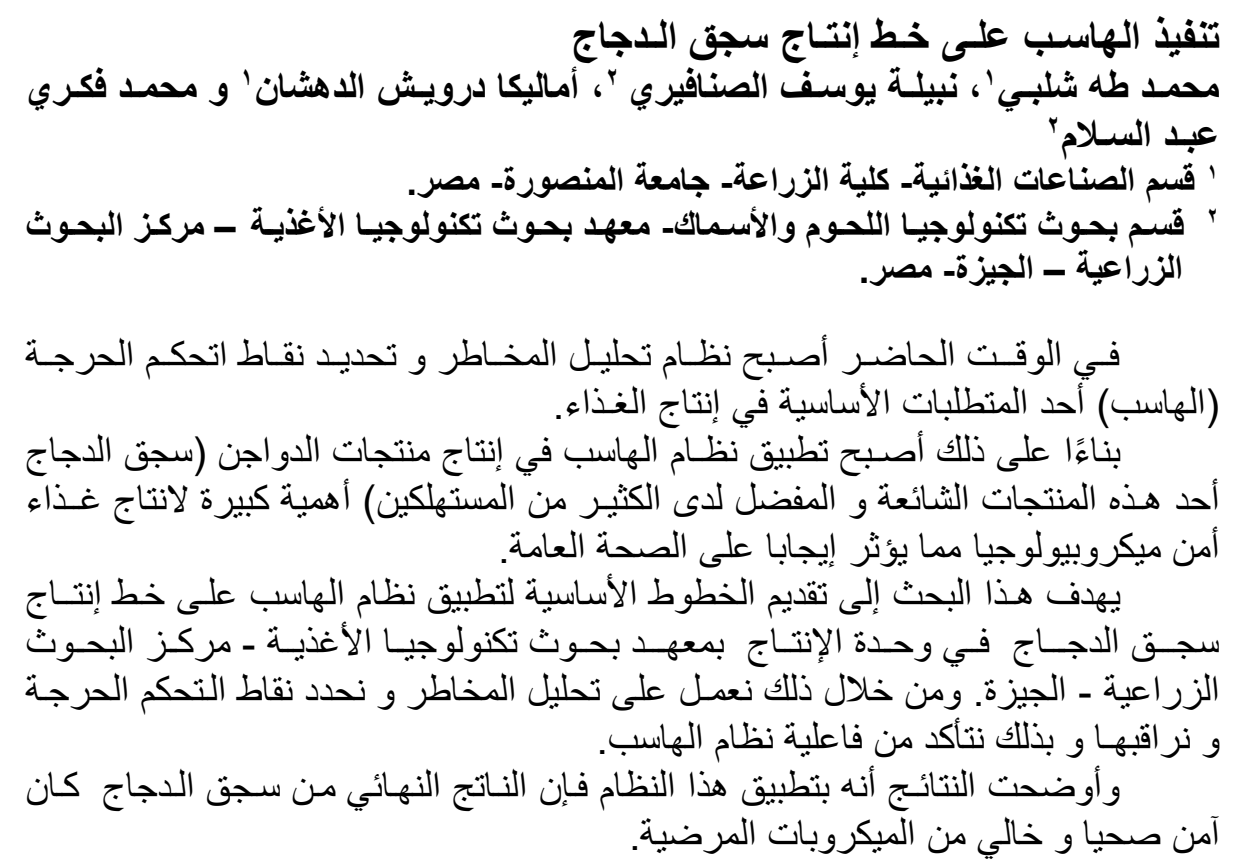

